\title{
PR PROC

\section{GIS application for damaged buildings assessment and shelter distribution analysis after earthquake and tsunami in Palu 2018}

Zealandia Sarah N. F., Sry Handini Puteri, Deha Agus Umarhadi, Ridho Dwi Dharmawan, Nur Mohammad Farda

Zealandia Sarah N. F., Sry Handini Puteri, Deha Agus Umarhadi, Ridho Dwi Dharmawan, Nur Mohammad Farda, "GIS application for damaged buildings assessment and shelter distribution analysis after earthquake and tsunami in Palu 2018," Proc. SPIE 11311, Sixth Geoinformation Science Symposium, 113110G (21 November 2019); doi: 10.1117/12.2548660

EDIE Event: Sixth Geoinformation Science Symposium, 2019, Yogyakarta, Indonesia 


\title{
GIS Application for Damaged Buildings Assessment and Shelter Distribution Analysis After Earthquake and Tsunami in Palu 2018
}

\author{
Zealandia Sarah N. Fa, Sry Handini Puteri ${ }^{\mathrm{a}}$, Deha Agus Umarhadi ${ }^{\mathrm{a}}$, Ridho Dwi Dharmawan ${ }^{\mathrm{ab}}$, Nur \\ Mohammad Farda ${ }^{\mathrm{a}}$ \\ ${ }^{a}$ Geographic Information System Laboratory, Faculty of Geography, Universitas Gadjah Mada, \\ D.I.Yogyakarta, Indonesia, 55281; ${ }^{\mathrm{M}} \mathrm{MSc}$ Student, Geo-Information for Spatial Planning and Disaster \\ Risk Management, Universitas Gadjah Mada, D.I.Yogyakarta, Indonesia
}

\begin{abstract}
Data and disaster information is crucial to support disaster response, recovery, and relief process. Unfortunately, acquiring data during emergency situations is difficult. After a disaster occurred, information about the victim and the impact of the disaster must be collected immediately for aid distribution purposes. Collecting shelter location data with number of victims and their needs must be completed swiftly as a disaster response action. Furthermore, collecting information of damaged buildings is also essential to determine the amount of compensation for destroyed houses. Geographic Information System combined with remote sensing is practical and reliable to help all of these tasks. WorldView-3 high resolution imagery with $0.5 \mathrm{~m}$ spatial resolution provided by Digital Globe is used to interpret damaged building in Palu City study area. By comparing satellite imagery before and after disaster, damaged building information can be interpreted and extracted as a cartographic map. Cross validation with field data of damaged building demonstrated that accuracy of the interpretation is approximately $80.49 \%$. The result of the damaged building compared with shelter distribution data using service area accessibility analysis and then used to analyze optimum coverage of disaster mitigation shelters.
\end{abstract}

Keywords: Palu-Earthquake, Tsunami, Building Damage Assessment, Shelter Distribution Analysis, GIS, Remote Sensing

\section{INTRODUCTION}

On 28th September 2018, a 7.4 Richter Scale earthquake hit Palu, Central Sulawesi, Indonesia'. This earthquake triggered a Tsunami that hit the coastal line of Talise which destroyed most of Palu City and Donggala area. Tsunami occured when there was a sudden and massive vertical displacement of ocean water in this case it was triggered by Palu earthquake ${ }^{2}$. According to BNPB, earthquake and tsunami in Palu cause 2101 people died, 133,631 people were evacuated, and 68,451 houses were damaged ${ }^{3,4}$. During the disaster, people were trapped in fear to come back to their houses, therefore they were living in a shelter as a temporary place to keep them safe. Shelter conditions and specifications were described in the BNPB chief regulation 2016 where in emergency state, the shelter shall be built based on the accessibility and effectivity ${ }^{7}$. Unfortunately, there were missing details about the full conduct of shelter distributions during emergency time. Role of disaster mitigation and management using remote sensing and Geographic Information System aplication is needed to collecting, processing and analysing of disaster data eficiently.

Remote Sensing and Geographic Information System (GIS) were well known to be the useful tools in disaster mitigation system. In the preparation of reconstruction, it was necessary to create the distribution of damaged buildings to acquired total loss information. Remote sensing data that can detect and monitor the physical characteristics of an earth surface is used to recognize damaged building based on interpretation $\mathrm{key}^{5}$. Apart from using remote sensing, it is also necessary to apply GIS to execute the acquired data and establish data to be visualized. GIS had been a common tool in the disaster mitigation system. A visualized map enabled the audience to understand the spatial distribution of the damaged buildings. Geography Information System (GIS) is a system designed to capture, store, manipulate, analyze, manage, and present all types of geographical data ${ }^{6}$. Emergency management professionals are using GIS for integrating data and

Sixth Geoinformation Science Symposium, edited by Sandy Budi Wibowo, Andi B. Rimba

Stuart Phinn, Ammar A. Aziz, Proc. of SPIE, Vol. 11311, 113110G · @ 2019 SPIE

CCC code: $0277-786 \mathrm{X} / 19 / \$ 21 \cdot$ doi: $10.1117 / 12.2548660$ 
enabling understanding of the scope of an emergency to manage an incident, determining how and where scarce resources should be assigned, and many more ${ }^{4}$.

Therefore, the aim of this research was to map the spatial distribution of damaged and destroyed buildings in Palu-Donggala after earthquake and tsunami 2018, Indonesia, using visual interpretion with study area illustrated in Figure 1. Shelter distribution and accesibility analysis also conducted to analyze optimum coverage of disaster mitigation shelters.
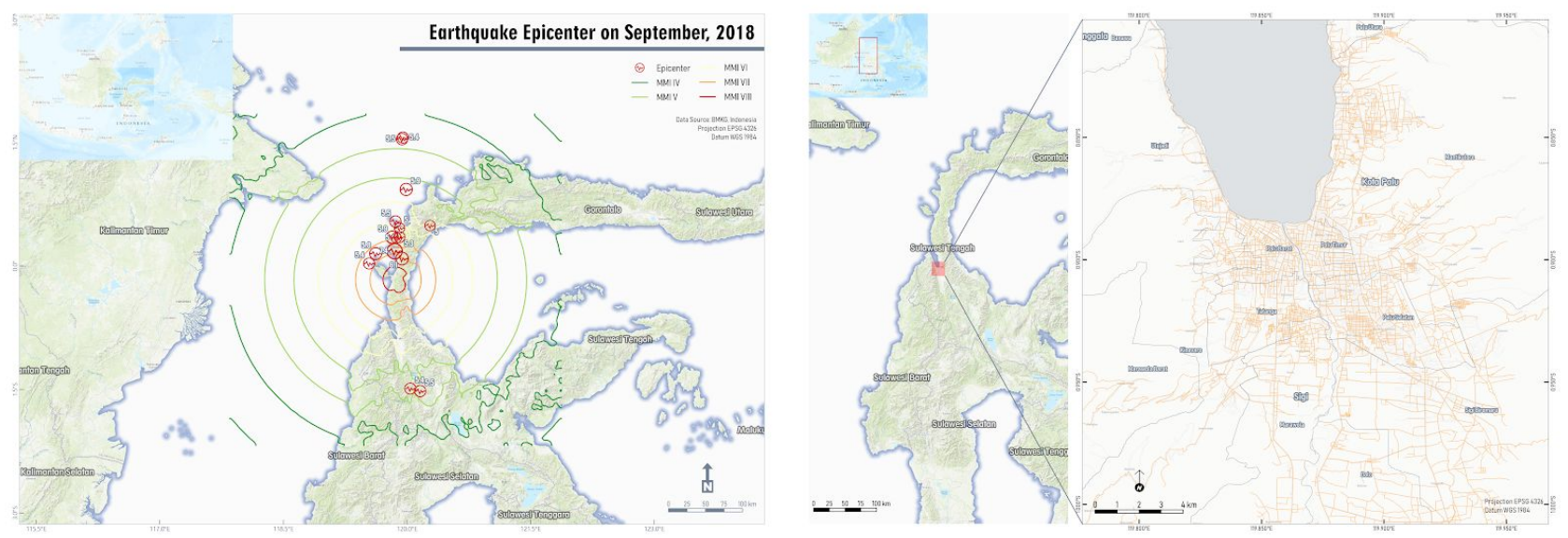

Figure 1. Earthquake map in Central Sulawesi on September 2018 (left) and study area located in Palu City and Kabupaten Sigi (right)

\section{MATERIALS AND METHODS}

\subsection{Study Area}

The study area selected in this research includes Palu City and some areas of Kabupaten Sigi. Palu is the capital city of Central Sulawesi and become the largest city in Sulawesi Tengah Province with a population of approximately 379,800 people in $2017^{8}$. This population consists of $12.73 \%$ of the total population in Central Sulawesi ${ }^{9}$. The total area of Palu is $395.06 \mathrm{~km}^{2}$. The northern border of Palu is Donggala district, the eastern border is Parigi Mautong, southern border is Sigi district, and the western border is West Sulawesi province. Palu City is located along the Palu-Koro fault that causes devastating effect when the earthquake ruptured on September $28,2018^{10}$ and spatially close to major fault lines which historically has a high epicenter density ${ }^{11}$.

\subsection{Satellite Imagery Data}

High resolution imagery satellite data were acquired before and after the disaster from DigitalGlobe Open Data Program ${ }^{12}$. The used satellite imagery is WorldView-3 provided by Digital Globe and Pleiades derived from the International Disaster Charter that can be accessed in inaRISK BNPB platform. The pre-disaster imagery acquired on 17th August 2018 and the post-disaster imagery captured on 1st October 2018. The Imageries of both conditions were interpreted to analyze the affected area. Each point represents one building that is divided into two categories; damaged and destroyed. A building was considered as damaged if there is a significant change at the building but the roof still remains intact. The building classed as destroyed is if the previous image shows that the building existed, but after comparing to the post-disaster image, the building is no longer exists or we can directly see the soil surface. All the damaged buildings were represented as points in the format of shapefile. This shapefile then was overlaid with the existing high-quality imagery to exhibit its spatial distribution in a map.

\subsection{Shelter distribution}

After the earthquake hit Palu and Donggala in $28^{\text {th }}$ September 2018, volunteers from Senior High School Madani Palu alumni collected the shelter location using google form which were distributed to people in Palu and Donggala city. Information obtained from this form were being transformed into a visualized map by Task Force team from GIS 
laboratory. The tabular information was translated into an elaborate map using Google MyMap. This effort was made to maximize the accessibility of information to multiple stakeholders such as BNPB, BPPD, NGOs who desired to help the victims. Geographical information system enable service area and accessibility analysis on shelter distribution data. We assessed the service area of shelters by applying network analyst based on the distance of the road. Compared to the Euclidean distance, this analysis involves the attribute of the road which represents the actual evacuation access ${ }^{13}$.

\section{RESULTS}

\subsection{Building damage assessment}

Building damage assessment result from visual interpretation was compared to after earthquake actual condition to assess the accuracy. The total number of samples collected was 123 samples consisting of 58 destroyed class, 33 damaged class, and 32 no significant damage class. The result of building damage interpretation and sample distribution map is shown in Figure 2, which depicts the location of sampling toward affected building. The location samples scattered in the coastal area, Palu downtown, and liquefaction area. The sampling distribution of each area is 17 in Ulujadi district, 17 in Palu Barat district, 18 in Palu Timur district, 14 in Palu Selatan district, 30 in Mantikulore district, 4 in Palu Utara district, and 23 in Sigi Biromaru district. Significantly affected buildings are concentrated in coastal areas due to the tsunami and also in soil liquefaction area. Building can completely destroyed because of Palu earthquake-triggered soil liquefaction which is caused by increased soil saturation so that loss its strength ${ }^{14,15}$.

The result of the cross validation is visualized on Figure 2 as a confusion matrix. Overall accuracy of the visual interpretation based on the calculation is $80.49 \%$. Producer and user accuracy of each building damage class also calculated and the result reached $37.5 \%$ of producer accuracy in no significant damage class being the lowest value among the others. It means, from 32 samples of no significant damage class, only 12 of them are correct according to the actual condition.
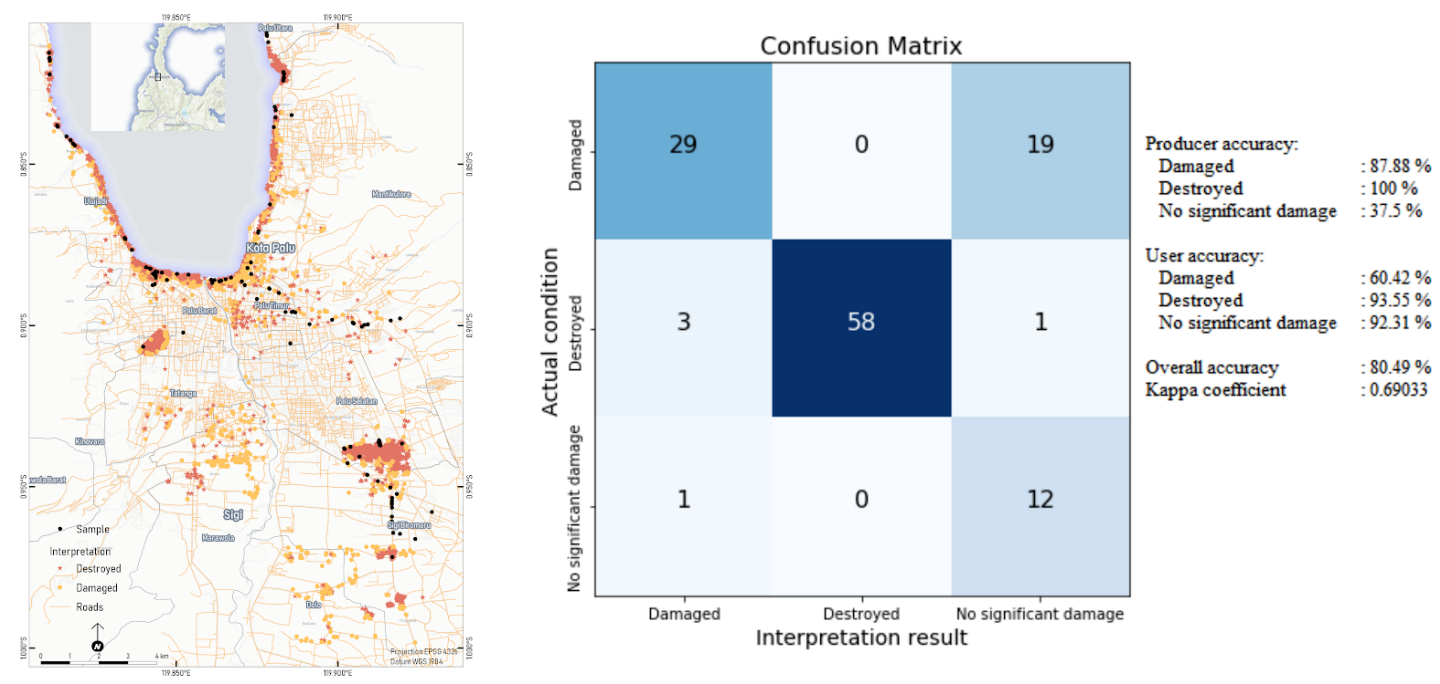

Figure 2. Building damage interpretation and sampling distribution (left) and the result of accuracy assessment (right)

Misclassification of visual interpretation occurred because it was difficult to observe the condition below the building roof on the imagery. Visual interpretation relied on the key interpretations of form and shadow which might be wrong. For example on the Figure 3 that shows the different appearance between top view of high resolution imagery with terrestrial photo. 


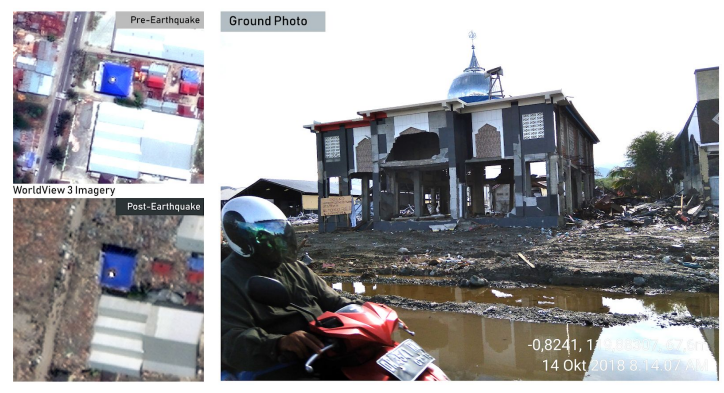

Figure 3. Comparison between WorldView 3 Imagery (before-after earthquake) and ground photo

\subsection{Shelter service area analysis}

The shelter distribution during the earthquake is sporadic and scattered. There is no significant pattern that can be recognized. From data that had been collected, there were 82 emergency shelters that we can identify. The data were acquired from BNPB shapefiles and several points reported by the local communities. The actual number of shelter might be higher in comparison to the gathered data because there are many NGOs that establish their shelters without cooperating with the center government. In such a situation, there was no central command to regulate the location of the shelter, thus it was not well-organized. Therefore, the shelter was independently established without any proper documentation to the responsible stakeholders.

Based on the 82 shelters that we managed to identify, most of them were located in the northern part of Palu, near Talise beach. The shelters mostly took place at the city center. The amount of shelters is consistently decreasing corresponding to the distance from the city center. The official shelter from BNPB can be seen in the blue dots. The red and yellow dots represent hospitals and victim's assembly point respectively. Main responsibilities of emergency shelters according to BNPB is command center of disaster emergency which their duties are coordination, control, monitoring, and evaluation of disaster emergency response process? ${ }^{7}$. When emergency status has been set, emergency shelters could be built considering accessibility and effectivity aspects.

Buffer network analysis is used to examine service coverage of every emergency shelters. Buffer tool helps to identify how far some point could cover its surrounding area. Considering Palu city width which only $395.06 \mathrm{~km}^{2}$, the result elucidates that one shelter is ideal for covering $0.5 \mathrm{~km}$ until $5 \mathrm{~km}$ wide. Figure 4 illustrates coverage area from 82 emergency shelters overlaid with distribution of affected buildings. Based on those maps, all of the affected buildings are covered by shelters service. Unfortunately, one shelter at Pelafa, Mantikulore district couldn't cover any affected buildings. Most destructed area at north of Palu city covered by 9 emergency shelter services. Moreover, at liquefaction area; Petobo sub-district, and Jono Oge village covered by 4 shelters.
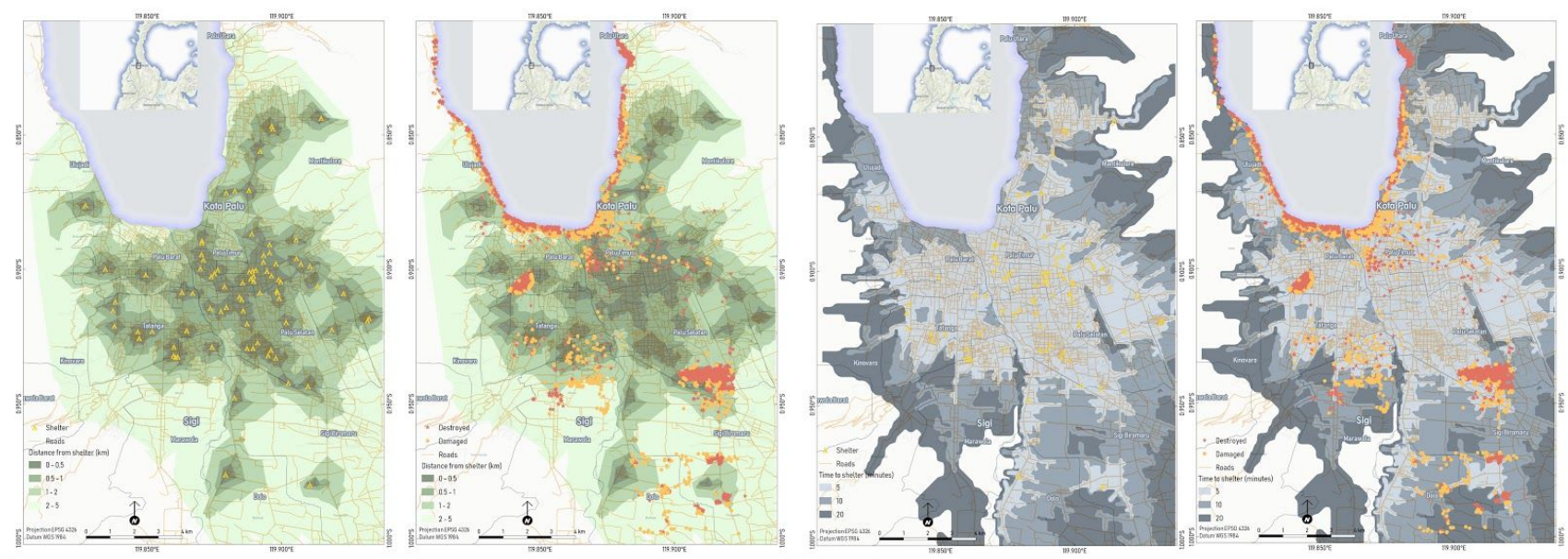

Figure 4. Distance-based service area analysis from shelter location (green) and time-based service area analysis from shelter location (grey) 


\subsection{Shelter accessibility analysis}

The shelter accessibility analysis is necessary to understand the proximity of the shelter to the main road access. The underlying assumption is people can only have mobility if the road is accessible. The main road selected for this research only includes a road that has a minimum width of 4 meters. This consideration refers to the accessibility of the road after the building collapsed because of the earthquake, where road closures are more often occurs on the road is less than 4 meters wide ${ }^{16}$. The main road is buffered using geographic information system (GIS) multiple ring buffers in a radius of 100 meters, 500 meters, and 1000 meters. Shelter located on a radius of 100 meters from the main road classified as high accessibility, 500 meters classified as medium accessibility, and 1000 meters classified as low accessibility. The result of buffer analysis is visualized on Figure 5 which displays the main road buffers and shelter points. The number of shelter on each radius multiple ring buffer is 31 shelters located on 100 meters, 43 shelters located on 500 meters, 7 shelters located on 1000 meters, and others located on more than 1000 meters from the main road.

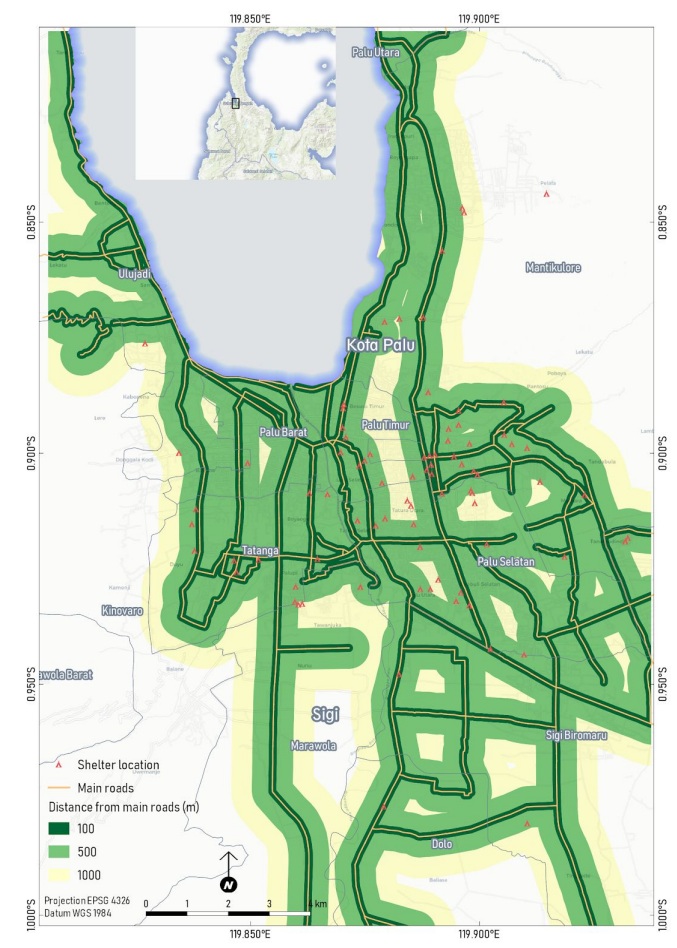

Figure 5. Distance from main roads

\section{CONCLUSION}

Visual interpretation on WorldView-3 high resolution imagery can produce accurate buildings assessment for totally destroyed building, but for interpreting damaged building is still need improvement, more detailed recognition of the interpretation key, and more information from ground survey. From the result of building damage interpretation, most of the destroyed area is covered shelter services with optimum range distance and time. The result of accessibility analysis from 82 shelters, there are 31 shelters which have high accessibility, 43 shelters have medium accessibility, and 7 shelters have low accessibility. 


\section{ACKNOWLEDGEMENT}

The data used in this research is the result of voluntary work of Task Force Spatial Data Support Team (TFPDS) nearly after the occurrence of Palu earthquake and tsunami in the collaboration between Geographic Information System Laboratory and Centre for Remote Sensing and Integrated Surveys (PUSPICS), Faculty of Geography, Universitas Gadjah Mada.

\section{REFERENCES}

[1] USGS, (United States Geological Survey), "Magnitude 7.5 Earthquake near Palu, Indonesia," $<$ https://www.usgs.gov/news/magnitude-75-earthquake-near-palu-indonesia> (1 July 2019).

[2] Roy, A.B., "Facts about Tsunami: Its Origin, Earthquake Link and Prediction: an Opinion," The Journal of Indian Geophysical Union 18(3), 330-335 (2014).

[3] BNPB, "Gempabumi Sulawesi Tengah," <https://sites.google.com/view/gempadonggala/beranda?authuser=0 > (18 July 2019).

[4] Indonesia, B., "Loss and Damage of Disaster in Central Sulawesi Reach 13,82 Trillion Rupiah - Badan Nasional Penanggulangan Bencana," $<$ https://www.bnpb.go.id/en/kerugian-dan-kerusakan-dampak-bencana-di-sulawesi-tengah-mencapai-1382-trilyu n-rupiah> (1 July 2019).

[5] Christopherson, J.B., Ramaseri Chandra, S.N., and Quanbeck, J.Q., "2019 Joint Agency Commercial Imagery Evaluation-Land Remote Sensing Satellite Compendium," U.S. Geological Survey, 191 (2019).

[6] Tomaszewski, B., [Geographic information systems (GIS) for disaster management], CRC Press Taylor \& Francis, Boca Raton (2015).

[7] BNPB, [Peraturan Kepala Badan Nasional Penanggulangan Bencana Nomor 03 Tahun 2016 tentang Sistem Komando Penanganan Darurat Bencana] (2016).

[8] Statistics of Sulawesi Tengah Province, B., [Sulawesi Tengah Province in Figures 2018], BPS-Statistics of Sulawesi Tengah Province, Sulawesi Tengah (2018).

[9] Statistics of Sulawesi Tengah Province, B., [Hasil Sensus Penduduk 2010 Provinsi Sulawesi Tengah: Data Agregat per Kabupaten/Kota] , BPS-Statistics of Sulawesi Tengah Province (2010).

[10] Bao, H., Ampuero, J.-P., Meng, L., Fielding, E.J., Liang, C., Milliner, C.W.D., Feng, T., and Huang, H., "Early and persistent supershear rupture of the 2018 magnitude 7.5 Palu earthquake," Nature Geoscience 12(3), 200-205 (2019).

[11] Dharmawan, R.D., Suharyadi, and Farda, N.M., [Geovisualization Using Hexagonal Tessellation for Spatiotemporal Earthquake Data Analysis in Indonesia], in Soft Computing in Data Science 788, A. Mohamed, M. W. Berry, and B. W. Yap, Eds., Springer Singapore, Singapore, 177-187 (2017).

[12] Digital Globe, "Satellite imagery for natural disasters," $<$ https://www.digitalglobe.com/ecosystem/open-data $>$ (5 July 2019).

[13] Unal, M., and Uslu, C., "GIS-Based Accessibility Analysis Of Urban Emergency Shelters: The Case of Adana City," ISPRS - International Archives of the Photogrammetry, Remote Sensing and Spatial Information Sciences XLII-2/W1, 95-101 (2016).

[14] Tomkins, A., and Spyrou, A., "Refraction Microtremor method for delineation of layers and lenses, and assessing liquefaction potential within an alluvial setting - Morobe Province, Papua New Guinea," ASEG Extended Abstracts 2018(1), 1-4 (2018).

[15] Hashim, H., Suhatril, M., and Hashim, R., "Assessment of liquefaction hazard along shoreline areas of Peninsular Malaysia," Geomatics, Natural Hazards and Risk 8(2), 1853-1868 (2017).

[16] Lee, Y., and Yeh, K., [Street Network Reliability Evaluation Following the Chi-chi Earthquake], in The Network Reliability of Transport, Elsevier, 273-288 (2003). 